Nig. J. Biotech. Vol. 34 (2017) 19-23

ISSN: 01891731

Available online at

http://www.ajol.info/index.php/njb/index

and www.biotechsocietynigeria.org

DOI: https://dx.doi.org/10.4314/njb.v34i1.3

\title{
Assessment of microalgae-influenced biodeterioration of concrete structures
}

\author{
Stanley H. ${ }^{1}{ }^{1}$, Onwukwe, C. D. ${ }^{2}$ and Peesor, S. D. ${ }^{2}$
}

'Department of Microbiology, Faculty of Sciences, University of Port Harcourt, P. M. B. 5323, Choba, 500004 Port Harcourt, Rivers State, Nigeria. 2Department of Microbiology Technology, School of Science and Laboratory Technology, University of Port Harcourt, P. M. B. 5323, Choba, 500004 Port Harcourt, Rivers State, Nigeria.

Copyright resides with the authors in terms of the Creative Commons License. 4.0 . See http://creativecommons.org/licenses/by/4.0/

Condition of use: The user may copy, distribute, transmit and adapt the work, but must recognize the authors and the Nigerian Journal of Biotechnology.

\section{Abstract}

The aim of this study was to isolate microalga involved in the biodeterioration of concrete structures. The growth of algae was monitored between day 1 and 18 using a spectrophotometer (Spectronic 721 model) at varying pH (4.2 and 9.4). To identify the microalgae, aliquots of the isolates was placed on microscope slides and observed with the microscope using $x 40$ Objective lens. Results revealed the highest growth to be between days 12 and 15 with 0.6 optical density, while the least growth was shown between 9 to 12 days. Microalgae isolated in the study include; Chlorella spp., Ulothrix spp., Xanthidium spp., Gleocystis spp., Nitzchia spp., Chlorodium spp., Oedogium spp., Synecoccus spp. and Chlorococcum. Chlorella showed the highest frequency of occurrence with $\mathbf{7 7 . 5 \%}$ while Ulothrix spp. and Xanthidium spp. had the least frequency of $12.5 \%$ respectively. The presence of these organisms on concrete structure suggests they contribute to its biodeterioration. There is need therefore to prevent colonization of structures by coating concrete surfaces using paints, epoxies and polymers.

Key words: Microalgae, Biodeterioration, Colonization and Concretes

Correspondence: Okehstanley@yahoo.com ; +2348035431710.

\section{Introduction}

Concrete is a composite material composed mainly of water, aggregate, and cement. Additives and reinforcements are often included in the mixture to achieve the desired physical properties of the finished material. (Lancaster, 2005). As an age long practice, Concrete has always being used for construction because of its durability and strength. Structures made of concrete are usually referred to as indestructible owing to the fact that they serve their purpose for a long time when compared to other products. Nevertheless, they can get deteriorated for a good number of reasons such as poor construction practices and quality design, hard exposure conditions with material limitations inclusive (Cwalina, 2008). Concrete can also be deteriorated by biological materials and a good perception of the physicochemical and biological processes associated with microbiologically induced concrete deterioration (MICD) is evolving (Trejo et. al., 2008). Algae can act as the collection platform for other corrosionrelated organisms such as fungi and bacteria, so that the deterioration process may gain momentum after the structure's conditions have become suitable for the survival of one of more such organisms. This collection of 
microorganisms is called a biofilm which consists of cells immobilised on a inert material, frequently embedded in an organic polymer matrix of microbial origin (Reza et. al., 2009). Biodeterioration effect leads to the production of metabolites (e.g. organic acids, dyes), which aggressively work with building materials and causing undesirable changes of their properties (Eštoková et. al., 2009). This study therefore aims to assess the microalgae involved in the biodeterioration of concretes.

\section{Materials and Methods}

Sample Collection

Scraping of deteriorating concrete structures were collected from four walls within University of Port Harcourt and surroundings using a sterile spatula. Samples were immediately transported to the Laboratory for analysis (Berebon et. al., 2014).

\section{Sterilization of Materials}

All the glasswares were sterilized by autoclaving at $121^{\circ} \mathrm{C}$ for $15 \mathrm{~min}$ at $15 \mathrm{psi}$ or by dipping into ethanol ( $95 \%$ alcohol) and flaming where necessary.

\section{Aeration}

The photoreactor flasks were taken to the herbarium unit of the department of Pant Science and Biotechnology section in University of Port Harcourt (Anderson, 2005) and sunlight was used to drive photosynthesis with natural aeration process where the flasks were manually shaken every 2 hours, to create room for oxygen to allow the cells thrive well in the medium (Iyoyo, 2010) and also to immobilize the cells in the liquid broth. The flask was shaken every two hours.

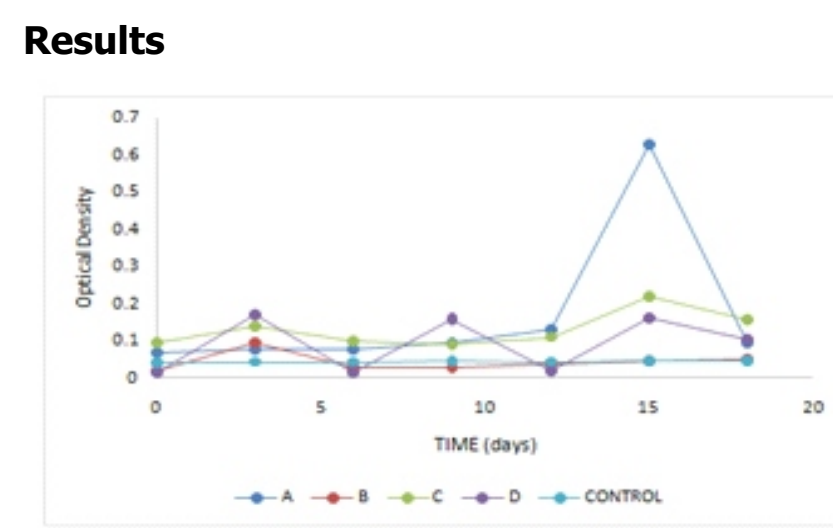

Fig. 1: Growth optimisation on sample loading using $1 \mathrm{ml}$ sample loading
Media

BG 11 medium and the Novel synthetic Medium was prepared and used according to manufacturer's instruction (Sirisansaneyakul et. al., 2011)

\section{Growth Monitoring \\ Optical Density}

The Optical Density (OD) was monitored with a spectrophotometer (Spectronic 721 model). Five milliliter $(5 \mathrm{ml})$ of the blooming culture was collected aseptically and placed in the cuvette, blanked with distilled water and absorbance measured at $600 \mathrm{~nm}$. (Feng et. al., 2012; Goncalves et. al., 2013; Kwon et. al., 2005)

\section{Optimization of $\mathrm{pH}$.}

The $\mathrm{pH}$ of the set-up was adjusted using the $0.1 \mathrm{~N}$ Hydrochloric acid and $0.1 \mathrm{~N}$ Sodium hydroxide. The Hannah pocket size $\mathrm{pH}$-meter was calibrated using buffer 7.5 solution. After which it was lowered into a $5 \mathrm{ml}$ aspirate of the culture broth (Mata et. al., 2012).

\section{Microalgae Identification}

An aliquot of the algal sample was placed on a slide and observed with x 40 objective lens. Pasteur pipette was used to suck out cells of the microalgae and was transferred into another watch glass containing $1 \mathrm{ml}$ of normal saline to obtain a unialgal culture of the microalgae and the process was continued until the microalgae were identified according to the scheme of Richmond (2004) based on their cultural and morphological characteristics.

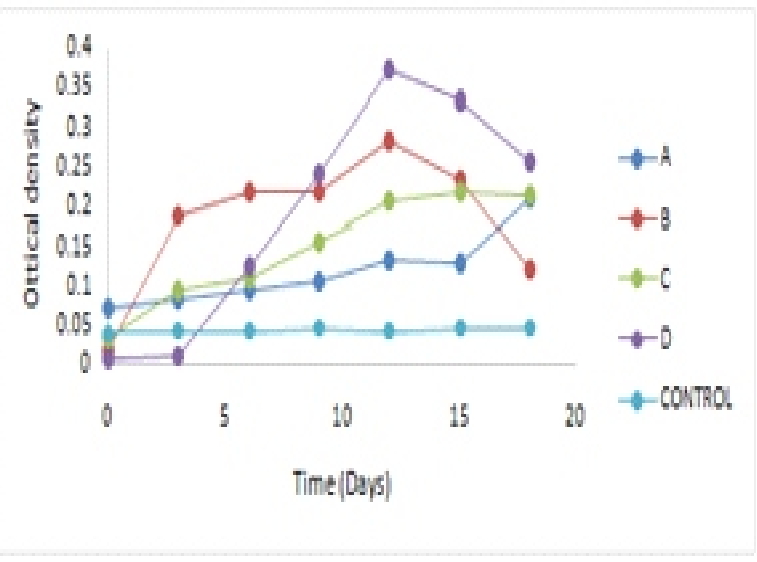

Fig. 2: Grouth optimisation on sample loading using double volume sample loading 


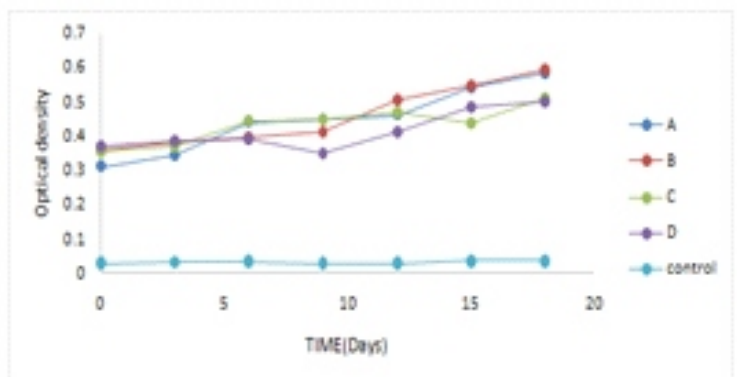

fig. 3: Growth monitoring at pH 4.2

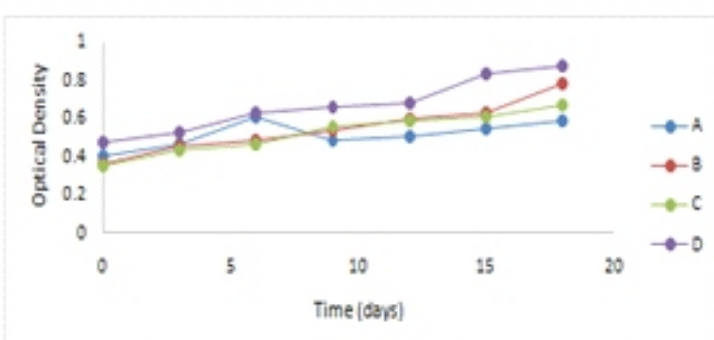

Fig. 4: Growth monitoring at pH 9.4

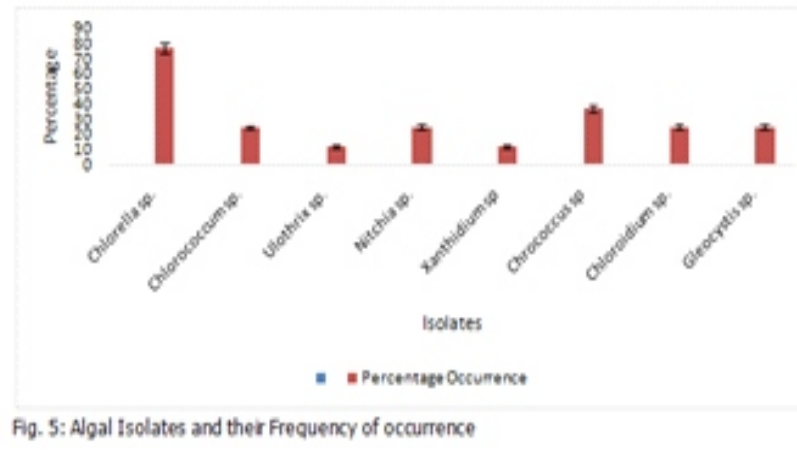

The growth optimization of microalgae was observed using single and double volume of samples. Using single volume at time zero, growth of algae in all samples was observed. There was a slight increase in growth between days 2 and 3 . On day 6 , there was a decrease in growth. Sample A showed an insignificant increase in growth between 0 and 12 days but experienced a significant growth increase from 0.1 to 0.6 OD between days 11 and 15 , followed by a drop on day 18 to $0.1 \mathrm{OD}$. A fluctuating growth between 0 to 0.2 OD was observed in sample D. similarly, a fluctuating growth was observed in sample $C$.

Using double volume of the different samples, sample A showed an insignificant growth increase between days 0 and 15, but experienced a significant increase between days 15 and 20 with OD value at 0.2. Sample B however showed a significant growth increase between day 0 and 3 with OD at 0.2. It further experienced an insignificant growth between days 3 and 9 . Between day 11 and 18, there was a decline in growth with OD at 0.1. Sample C showed a corresponding increase in growth between day 0 and 8 and OD between 0 to 0.2 . Sample $D$ showed an insignificant increase between day 0 and 3 but showed a significant growth increase between day 3 and 11 with OD between 0 to 0.36 . It experienced a decrease between day 11 and 18 with OD at 0.25 . The rapid increase and decrease in growth at increasing OD showed could be as a result of the fluctuating environmental conditions. Cellular composition, photosynthesis, algae growth rate and metabolism are affected by environmental factors viz; light, nutrients $\mathrm{pH}$ and temperature. (Visviki and Santikul, 2000).

The growth of algae at $\mathrm{pH} 4.2$ and 9.4 was also observed. At $\mathrm{pH} 4.2$, all samples showed fluctuating growth with OD between 0.3 and 0.6 but at $\mathrm{pH} 9.4$ there was a less fluctuating growth with $\mathrm{OD}$ between 0.3 and 0.8 . This implies the growth of algae is more favorable at $\mathrm{pH}$ 9.4. Maximum algal growth occurs around neutral $\mathrm{pH}$, although optimum $\mathrm{pH}$ is the initial culture $\mathrm{pH}$ at which an alga is adapted to grow (Juneja et. al., 2013). pH is a major factor in algal cultivation. This is because it determines the solubility and availability of $\mathrm{CO}_{2}$ and essential nutrients, and can have a significant impact on algal metabolism (Juneja et. al., 2013). In the present study; Chlorella spp., Ulothrix spp., Xanthidium spp., Gleocystis spp., Nitzchia spp., Chlorodium spp., Oedogium spp., Synecoccus spp. and Chlorococcum spp. were isolated. 
Chlorella spp. showed the highest frequency of occurrence with $77.5 \%$, followed by Chrococcus spp. (37.5\%). Chloroidium spp, Gleocystis spp. and Nitchia spp. had a frequency of occurrence of $25 \%$ respectively. Chlorococcum spp. had a percentage frequency of 25 while Ulothrix spp. and Xanthidium spp had a frequency of $12.5 \%$ respectively. This wide range of algae on deteriorating concrete suggests they are involved in the process of deterioration. Similarly, Jayakumar et. al. (2011) showed that algae have been involved in the deterioration of concrete structures. Algae are photosynthetic microorganism. Photosynthesis is a process during which the atmospheric carbon dioxide is converted to organic carbon. During photosynthesis carbon dioxide and water produce glucose and oxygen. It is this oxygen that can play an important role in one of the possible scenarios for the deterioration of concrete. These organisms can also play a role in the damage to concrete due to the fact that algae are capable of excreting organic acids (Stanciu and Bordei, 2005)

\section{Conclusion}

Results have shown that a wide range of algae are present in deteriorating concrete structure and participate in the process of deterioration; by creating an enabling environment for bacterial and fungi succession and the presence of these organisms has largely been influenced by environmental factors such as availability of nutrients, optimal $\mathrm{pH}$ and temperature hence creating an enabling environment for these organisms to thrive. The production of organic acid by algae has also contributed to the deterioration of concrete structures. There is need therefore to prevent colonization of structures by algae. This can be achieved by Coating concrete surfaces using paints, epoxies and polymers and surface cleaning where possible using chemical or biological means (biocides).

\section{References}

Anderson, R. A. (2005). Algal culturing technique. Elsevier Academic Press Burlington Mass. 578 - 600.

Cwalina, B. (2008). Biodeterioration of Concrete. Arch CivEngin Enviro(4): 133 - 140.

Estokova, A., Luptakova, A., Harbulakova, V. and Stevulova, N. (2009). Biodeterioration of composite based on coal fly ash. In: CEST 2009: Proceedings of the 11 th International Conference on Environmental Science and Technology: 3-5 September 2009, Chania, Crete, Greece. Chania: University of the Aegean.

Feng, P., Deng, L. F. and Hu, Z. (2010). Lipid accumulation and growth characteristics of Chlorella zofingiensis under nitrate and phosphate concentrations. J of Bio and Bioeng. 114: 405 - 410.

Goncalves, A. L., J. C. M. Pires and Simones, M. (2013). Lipid Production of Chlorella vulgaris and Pseudokirneriella subcapitata. Inter J Ener and Environ Eng. 4(14): 1 - 6.

Juneja, A., Ceballos R. M., and Murthy G. S., (2013). Effects of Environmental Factors and Nutrient Availability on the Biochemical Composition of Algae for Biofuels Production: A Review. Energies. 6: 4607 - 4638.

Kwon, B, Park, N and Cho, J (2005). Effect of Algae on Fouling and Effect of UF Membrane desalination. 179: $203-214$.

Lancaster, L. (2005). Concrete Vaulted Construction in Imperial Rome. Innovations in Context. Cambridge University Press. ISBN 9780-511-16068- 4.

Mata T. M., Martins A. A., and Ceatano, N. S. (2010). Microalgae for Biodiesel Production and other Application: A Review. Renewable Energy Review 14: 217 - 232. 
Reza, J., Hamid N., Michael B., Navid M and Monita O. (2009). On the Impact of Algae on Accelerating the Biodeterioration / Biocorrosion of Reinforced Concrete: A Mechanistic Review. Euro J Sci Res. 36 (3): 394 - 406.

Sirisaneyakul, S., Singhasuwan, S., Choorit, N, Phoopat, J., Garcia and Chisti, Y. (2006). Phototrophic Production of Lipids by some Chlorella strains. Marine Biotechnology. 13: 928 $-941$.

Stanciu, C., and Bordei, M. (2005). Aspects Regarding the biocorroison of the paper manufactured machines", The Annals of
"Dunarea De Jos. University of Galati Fascicle IX Metallurgy and Materials Science, ISSN1453, 083XNR1.

Trejo, D., de Figueiredo, P., Sanchez, M., Gonzalez, C., Wei, S. and Li, L. (2008). Analysis And Assessment Of Microbial Biofilm-Mediated Concrete Deterioration. Technical Report Documentation Page.

Visviki, I. and Santikul, D. (2000). The pH tolerance of Chlamydomonas applanata (Volvocales, Chlorophyta). Arch. Environ. Contam. Toxicol., 38: 147 - 151. 